\title{
INDUSTRY 4.0 READINESS ASSESSMENT FOR SOUTH AFRICAN INDUSTRIES
}

\author{
W. Maisiri ${ }^{1 * \#}$ \& L. van Dyk ${ }^{2}$
}

\section{ARTICLE INFO}

Article details

Presented at the $30^{\text {th }}$ annual conference of the Southern African Institute for Industrial Engineering (SAIIE), held from 30 September - 2 October 2019 in Port Elizabeth, South Africa

Available online 15 Nov 2019

\section{Contact details}

Corresponding author wmlisper27@gmail.com https://orcid.org/0000-0002 4892-2675

\section{Author affiliations}

1 School of Industrial Engineering, North-West University, South Africa

2 Faculty of Engineering, NorthWest University, South Africa

\# The author is enrolled for a PhD (Industrial Engineering) degree in the School of Industrial Engineering, North-West University, South Africa
Technological advancements related to the fourth industrial revolution are causing disruptive changes that are widely felt at national, industry, and company level. Industry 4.0, an initiative driving the fourth industrial revolution, is happening at an exponential speed, and embracing and adopting it is unavoidable for survival and competiveness. Although noticeable progress has been made in the use of Industry 4.0 technologies, systems, and processes in developed countries, there is uncertainty about the preparedness of businesses and industries in developing countries, including South Africa, to adopt Industry 4.0. The purpose of this research paper is to explore the readiness of South African industry in this regard. A questionnaire instrument with quantitative criteria compiled by the Impulse Foundation of Verband Deutscher Maschinen- und Anlagenbau was used in this study. The exploratory study revealed that South African industry is faced with significant challenges in Industry 4.0 strategy formulation and equipment infrastructure to support Industry 4.0 requirements. The assessment pointed out that Industry 4.0 skills exist in pockets in South Africa, and so a further study to reveal more detail on Industry 4.0 skills requirements is essential.

\section{OPSOMMING}

Tegnologiese ontwikkelings met betrekking tot die vierde industriële rewolusie veroorsaak verreikende ontwrigtende verandering op nasionale, industrie-, en besigheidsvlak. Industrie 4.0, 'n inisiatief wat die Vierde Industriële Rewolusie aanvuur, geskied teen eksponensiële spoed en dit is noodsaaklik om dit te aanvaar en toe te pas, met die oog op oorlewing en mededingendheid. Alhoewel daar beduidende vordering is met betrekking tot die implementering van Industrie 4.0 in ontwikkelde lande, is daar onsekerheid oor die gereedheid van ontwikkelende lande, insluitend Suid-Afrika, om Industrie 4.0 te implementeer. Die doel van hierdie artikel is om die gereedheid van Suid-Afrikaanse industrieë in hierdie opsig te verken. 'n Vraelys-instrument met kwantitatiewe kriteria wat deur die Impulse Foundation van Verband Deutscher Maschinen- und Anlagenbau saamgestel is, is in hierdie studie gebruik. Die verkennende studie het getoon dat die Suid-Afrikaanse industrie beduidende uitdagings in die gesig staar wat betref strategieformulering en toerustinginfrastruktuur om Industie 4.0-eise te bevredig. Die ondersoek het getoon dat Industrie 4.0-vaardighede in geïsoleerde situasies in Suid-Afrika bestaan, en daarom is verdere studie om meer oor die vereistes vir Industrie 4.0-vaardighede te wete te kom, dringend nodig.

\section{INTRODUCTION}

The era of Industry 4.0 is upon us, and alignment with its requirements is inevitable for survival and competitiveness. Industry 4.0 is happening at an exponential rate, and facilitating its successful 
adoption in developing countries, South Africa included, is of significance for sustainable development.

Industry 4.0, a term coined in Germany $[1,2]$ to define a well-proven and established initiative driving the fourth industrial revolution [3,4] and used by experts to describe it [5-7], has three distinct features that differentiate it from Industry 3.0 [8]: (a) the exponential pace at which technology is evolving; (b) the breadth and depth of technological advancement, which combines multiple technologies; and (c) the extent of the impact across the entire system, thus affecting companies, industries, and whole countries. This means that the disruptive effects of Industry 4.0 are widely felt at all levels, and require action to deal with their impact.

Rajnai and Kocsis [9] pointed out three pillars of Industry 4.0's technologies: information accessibility on a real-time basis; the ability to use data for optimisation at all times; and "integration of people, objects and systems into the value chain" [9]. On the other hand, Bittighofer et al. [10] singled out moving from mass production to the customisation of products and services as an attribute of Industry 4.0.

The purpose of this research paper is to explore the readiness of South African industries to adopt Industry 4.0. The paper reports on organisations' readiness to embrace Industry 4.0 across six readiness dimensions: organisational strategy, infrastructure, operations, products, data-driven services, and employees' skills availability.

In this paper, an overview of an Industry 4.0 readiness assessment is presented first in section 2 . Section 3 outlines the methodology that was followed to perform this study. The survey's results and an analysis of them are presented in section 4 , with a discussion of the results offered in section 5. Section 6 states the conclusions of this exploratory investigation.

Organisations can gain an understanding of their preparedness level by using Industry 4.0 readiness assessment tools [9]. Such tools can be used to benchmark and map an organisation's direction for successful digital transformation. Thus a successful journey of adopting Industry 4.0 can be initiated by performing an Industry 4.0 readiness assessment, which will help to identify focus areas that demand attention. Industry 4.0 readiness assessments can be performed in different structures, such as in a department in an organisation, in the entire organisation, or at a national level $[11,12]$.

Botha [13] pointed out that Industry 4.0 is a reality, and that its influence on how business is done cannot be avoided. Embracing Industry 4.0 is the way to remain competitive and relevant in the future. In the Industry 4.0 era, data will be recognised as an important asset, and competitiveness will hang upon organisations' ability to collect and analyse data for continuous improvement [14].

Industry 4.0 readiness extends beyond investing in advanced technologies by including issues such as organisational strategy and the availability of skills. Digital transformation is not an abrupt change; rather, it is a gradual change that includes many stages [9]. Accepting the point made by Rajnai and Kocsis [9], it is concluded that an Industry 4.0 readiness assessment seeks to identify the phase of an organisation in relation to digital transformation.

Organisations involved in a study by Judit [14] stated that Industry 4.0 was important, and that its impact was already being felt in the industry. Contrary to the findings of Judit [14], however, Rajnai and Kocsis [9] pointed out that surveys proved that a significant number of company leaders attested that, at the time of the surveys, they were not aware of Industry 4.0. The authors concluded that, amidst the hype, there was a possibility that the leaders of organisations were unaware of Industry 4.0.

\section{RESEARCH METHODOLOGY}

The primary objective of this study is to explore the Industry 4.0 readiness level of South African industries by obtaining quantitative primary data from individuals holding management positions. A quantitative research methodology is used in this study, and was chosen because calculating the Industry 4.0 readiness level requires chosen indicators to be scored. This section is organised as 
follows: section 3.1 outlines the available Industry 4.0 readiness assessment tools, and section 3.2 presents the Industry 4.0 readiness assessment indicators applied in this study. The questionnaire structure that was used in data collection is presented in section 3.3. The sampling technique and data analysis method are presented in section 3.4 and section 3.5 respectively.

\subsection{Readiness assessment tools}

A notable number of Industry 4.0 readiness assessment tools are in existence and are assessed in this section. In a review of the developmental stages of Industry 4.0, Judit outlined a macro- and micro-level Industry 4.0 readiness index by Blanchet, Rinn, von Thaden and de Thieulloy [15] and Geissbauer, Vedso and Schrauf [16] respectively. The macro-level Industry 4.0 readiness index classifies countries' Industry 4.0 readiness into four categories, as presented in Table 1.

Table 1: Industry 4.0 readiness categories at macro-level $[14,15]$

\begin{tabular}{l|l}
\hline $\begin{array}{l}\text { Industry } \\
\text { category }\end{array}$ & readiness \\
\hline Frontrunners & $\begin{array}{l}\text { Manufacturing has a large share in the GDP, innovative, dictate technologies, } \\
\text { path leaders. }\end{array}$ \\
\hline Potentialists & $\begin{array}{l}\text { Manufacturing on downward trend in previous years, innovative attitudes, } \\
\text { and pathfinders. }\end{array}$ \\
\hline Traditionalists & $\begin{array}{l}\text { Manufacturing has noticeable share in the GDP, underdeveloped technologies } \\
\text { and production methods. }\end{array}$ \\
\hline Hesitators & $\begin{array}{l}\text { Manufacturing and technology require development, uncertainty in adopting } \\
\text { digitalisation. }\end{array}$ \\
\hline
\end{tabular}

The micro-level Industry 4.0 readiness index distinguishes four discrete development levels to which organisations can belong [9, 14]. Table 2 presents the categories of Industry 4.0 development through which organisations can go.

Table 2: Industry 4.0 readiness categories at micro-level $[14,16]$

\begin{tabular}{l|l}
\hline $\begin{array}{l}\text { Industry } \\
\text { readiness category }\end{array}$ & Description \\
\hline Digital novices & $\begin{array}{l}\text { Isolated digital applications and solutions, focus on products and not customers, } \\
\text { operate in functional silos, manual data collection dominates, fragmented IT } \\
\text { architecture. }\end{array}$ \\
\hline Vertical integrators & $\begin{array}{l}\text { Emphasis on digitalisation, unstructured cross-functional collaboration, isolated } \\
\text { analytical capabilities, limited integration with external supply chain. }\end{array}$ \\
\hline $\begin{array}{l}\text { Horizontal } \\
\text { collaborators }\end{array}$ & $\begin{array}{l}\text { Digitalisation activities across the whole value chain (internal and external), } \\
\text { thorough data use, comprehensive data analytics, central business intelligence } \\
\text { manages information sources (internal and external). }\end{array}$ \\
\hline Digital champions & $\begin{array}{l}\text { Develop novel digital models, collaboration extends beyond value chain partners, } \\
\text { completely digitised with their partners, use of predictive analytics in real-time } \\
\text { optimisation. }\end{array}$ \\
\hline
\end{tabular}

Rajnai and Kocsis [9] noted Forrester's four digital maturity dimensions: culture, technology, organisation, and insights. The digital maturity readiness level of the stated digital maturity dimensions can be evaluated using a set of criteria of four maturity levels, as presented in Table 3.

Table 3: Forrester's four levels of digital maturity readiness levels [9]

\begin{tabular}{l|l}
\hline Digital maturity readiness level & Characteristic \\
\hline Differentiators & Leveraging data to meet customer requirements \\
\hline Collaborators & "Breaking down traditional silos” \\
\hline Adopters & “Investing in skills and infrastructure” \\
\hline Sceptics & Starting the digital transformation journey \\
\hline
\end{tabular}

Siemens [5] discusses four different Industry 4.0 maturity levels, as presented in Table 4 . The reviewed literature points out that a significant number of authors use a four-level maturity model. 
Table 4: Industry 4.0 maturity levels

\begin{tabular}{c|l|c}
\hline $\begin{array}{l}\text { Maturity } \\
\text { level }\end{array}$ & Description & Criteria (P) \\
\hline Emerging & Companies that are struggling to start digital transformation initiatives & $<35 \%$ \\
\hline Developing & $\begin{array}{l}\text { Companies have embarked on initial steps towards digital transformation, } \\
\text { but still face obstacles to progress. }\end{array}$ & $35 \%<\mathrm{P} \leq 65 \%$ \\
\hline Established & $\begin{array}{l}\text { Significant strides have been taken in the digital transformation journey, } \\
\text { with room for improvement in some areas. }\end{array}$ & $65 \%<\mathrm{P} \leq 90 \%$ \\
\hline Advanced & $\begin{array}{l}\text { Companies have adopted digital transformation, and are regarded as } \\
\text { mature. }\end{array}$ & $90 \%<\mathrm{P} \leq 100 \%$ \\
\hline
\end{tabular}

Rajnai and Kocsis [9] and Basl and Koop [17] discuss the Impulse Foundation of Verband Deutscher Maschinen- und Anlagenbau (VDMA) "Industrie 4.0 Readiness" self-assessment tool [18, 19], which is built upon six dimensions: organisational strategy, smart factory, smart operations, smart products, data-driven services, and employees [9, 18, 19].

In the VDMA survey, each of the six dimensions is evaluated, and the overall readiness score is obtained from the weighted average score. Table 5 presents the weighted score for each of the six dimensions considered. The VDMA "Industrie 4.0 Readiness" [19] model has six readiness levels, described in Table 6. Basl and Kopp [17], in their study evaluating the readiness of Czech companies, used the VDMA readiness model and categorised the preparedness levels using the criteria presented in Table 6 [17].

Table 5: Dimensions' weighted scores [9, 19]

\begin{tabular}{c|c}
\hline Dimensions & Weighted Score \\
\hline Organisational strategy & $25 \%$ \\
\hline Smart factory & $14 \%$ \\
\hline Smart operations & $10 \%$ \\
\hline Smart products & $19 \%$ \\
\hline Data-driven services & $14 \%$ \\
\hline Employees & $18 \%$ \\
\hline
\end{tabular}

Table 6: Industry 4.0 preparedness categories $[17,19]$

\begin{tabular}{|c|c|c|}
\hline Readiness level & Description & Criteria \\
\hline Level 0: Outsider & $\begin{array}{l}\text { - Either no requirement is met, or Industry } 4.0 \text { is unknown and } \\
\text { irrelevant. }\end{array}$ & 0 \\
\hline Level 1: Beginner & $\begin{array}{l}\text { - Pilot initiatives in Industry } 4.0 \text {, investments in single area. } \\
\text { - Infrastructure partially meets future requirements. } \\
\text { - Skills are found in few areas. }\end{array}$ & $0<$ Points $\leq 50$ \\
\hline $\begin{array}{l}\text { Level } \\
\text { Intermediate }\end{array}$ & $\begin{array}{l}\text { - Incorporating Industry } 4.0 \text { into the company strategy. } \\
\text { - Investments in noticeable number of areas. } \\
\text { - Partial automation in collection of data. } \\
\text { - Skills available in some areas to pursue Industry 4.0. }\end{array}$ & $50<$ Points $\leq 90$ \\
\hline $\begin{array}{l}\text { Level } \\
\text { Experienced }\end{array}$ & $\begin{array}{l}\text { - Strategy formulated. } \\
\text { - Investments in significant number of areas. } \\
\text { - Infrastructure may be upgradable. } \\
\text { - Security in place for the information technology systems. }\end{array}$ & $\begin{array}{l}90<\text { Points } \leq \\
120\end{array}$ \\
\hline Level 4: Expert & $\begin{array}{l}\text { - Industry } 4.0 \text { strategy in use. } \\
\text { - Investment achieved in almost the entire organisation } \\
\text { - Large amounts of data collected automatically and used for } \\
\text { optimisation purposes. } \\
\text { - Availability of add-on information technology functionality in } \\
\text { the products. }\end{array}$ & $\begin{array}{l}120<\text { Points } \leq \\
145\end{array}$ \\
\hline $\begin{array}{l}\text { Level 5: } \quad \text { Top } \\
\text { performer }\end{array}$ & $\begin{array}{l}\text { - Industry } 4.0 \text { strategy implemented and monitored for progress. } \\
\text { - Industry } 4.0 \text { investments in the entire company } \\
\text { - Infrastructure satisfies all Industry } 4.0 \text { requirements. }\end{array}$ & $\begin{array}{l}145<\text { Points } \leq \\
160\end{array}$ \\
\hline
\end{tabular}

Samaranayake, Ramanathan, Laosirihongthong [20] discussed the factors that influence digital transformation readiness, but did not present an Industry 4.0 readiness model. Six technological 
readiness dimensions were formulated: "improve and develop the internet system, knowledge of humans in technology and how to use it, improve ability of machine and device in connecting to internet, ability to manage big data, data sharing between or within organisation and develop the data security system"[20].

Industry 4.0 is a moderately new phenomenon [20]; so Rajnai and Kocsis [9] point out that there is no an universally agreed and proven methodology for assessing Industry 4.0 readiness. Thus the contribution by Botha [13] on the characteristics of the future readiness model to assess the Industry 4.0 readiness level is acknowledged. Botha [13] outlines a conceptual readiness model that will direct the evaluation of future readiness for Industry 4.0. Technology, the behaviour of both the external and internal markets (workforce and workers), and events were identified as the futureshaping factors in assessing the Industry 4.0 readiness level [13]. Although this contribution is substantial, it is not within the scope of this research, which seeks to explore the current readiness of South African industries to implement Industry 4.0 technologies and design principles.

The Industry 4.0 readiness assessment by VDMA $[18,19]$ is a well-grounded tool that has been used and suggested by researchers to perform exploratory Industry 4.0 readiness assessments $[9,17,21]$. Thus, to perform this exploratory study, the VDMA assessment tool was chosen from the existing and available Industry 4.0 readiness assessment tools. In line with good ethical practice, permission to use the VDMA questionnaire for research purposes was obtained.

\subsection{Industry 4.0 readiness assessment indicators}

Using the concept of indicators applied by Siemens [5], this study identified possible indicators to be used in the assessment of the Industry 4.0 readiness level. These indicators were formulated using the study by the VDMA [19], and are presented in Table 7.

Table 7: Industry 4.0 readiness assessment $[5,19]$

\begin{tabular}{|c|c|c|}
\hline Category & Sub-category & Indicator \\
\hline \multirow{4}{*}{$\begin{array}{l}\text { Organisational } \\
\text { strategy }\end{array}$} & $\begin{array}{l}\text { Industry } 4.0 \text { strategy } \\
\text { implementation }\end{array}$ & $\begin{array}{l}\text { - Strategy implementation status } \\
\text { - Strategy compatibility with overall } \\
\text { organisational strategy }\end{array}$ \\
\hline & Organisational investments & $\begin{array}{l}\text { - Number of distinct areas with investments or } \\
\text { plans to invest in Industry } 4.0\end{array}$ \\
\hline & $\begin{array}{l}\text { Systematic technology and } \\
\text { innovation management }\end{array}$ & $\begin{array}{l}\text { - Number of distinct areas with systematic } \\
\text { technology and innovation management }\end{array}$ \\
\hline & Industry 4.0 technologies & - Number of technologies in use \\
\hline \multirow{4}{*}{$\begin{array}{l}\text { Organisational } \\
\text { infrastructure }\end{array}$} & Equipment functionalities & $\begin{array}{l}\text { - Level of use of IT to control machine systems } \\
\text { - Level of use of Machine to Machine } \\
\text { communication } \\
\text { - Level of machines' interoperability }\end{array}$ \\
\hline & $\begin{array}{l}\text { Equipment functionalities' } \\
\text { adaptability }\end{array}$ & $\begin{array}{l}\text { - Level of use of M2M communication } \\
\text { - Level of machines' interoperability }\end{array}$ \\
\hline & Digital modelling & - Machine data collection and processing \\
\hline & $\begin{array}{l}\text { Systems, and interface to leading } \\
\text { system }\end{array}$ & $\begin{array}{l}\text { - Number of systems in use } \\
\text { - Number of systems in use with leading interface }\end{array}$ \\
\hline \multirow{3}{*}{$\begin{array}{l}\text { Smart } \\
\text { operations }\end{array}$} & $\begin{array}{l}\text { Cross-departmental information } \\
\text { sharing }\end{array}$ & $\begin{array}{l}\text { - Number of departments with internal integrated } \\
\text { cross-departmental information sharing } \\
\text { - Number of departments with external integrated } \\
\text { cross-departmental information sharing }\end{array}$ \\
\hline & Autonomous functionality & $\begin{array}{l}\text { - Availability of autonomous workpiece guides } \\
\text { - Availability of autonomous production process } \\
\text { response in real time }\end{array}$ \\
\hline & IT solutions & $\begin{array}{l}\text { - IT organisation } \\
\text { - Security solutions implementation level } \\
\text { - Use of cloud services }\end{array}$ \\
\hline Smart products & $\begin{array}{l}\text { Products functionality based on } \\
\text { ICT }\end{array}$ & - Number of add-on functionalities \\
\hline $\begin{array}{l}\text { Data-driven } \\
\text { services }\end{array}$ & Data usage and analysis & $\begin{array}{l}\text { - Use of data and process data to enable new } \\
\text { services } \\
\text { - Use of data analytics }\end{array}$ \\
\hline Employees & Industry 4.0 skills & - Level of existing skills \\
\hline
\end{tabular}




\subsection{Questionnaire structure}

A questionnaire instrument with quantitative criteria was used as the research strategy in this study. The employed questionnaire instrument was adopted from a study performed by VDMA [18], with a few questions changed and modified to suit South African industries.

After making the necessary changes, the questionnaire instrument consisted of one qualitative question to investigate respondents' understanding of what Industry 4.0 is, and 23 quantitative questions. The questions were grouped into the following sections:

Section 1: General questions, which sought to gather respondents' information, such as industry type, organisational size, position, and general understanding of the term 'Industry 4.0'.

Section 2: Organisational strategy questions that assessed the strategy implementation status, organisational compatibility with Industry 4.0, and level of investment in Industry 4.0 initiatives. The section further identified technologies that the organisation was actually using at the time of the survey.

Section 3: Infrastructure questions sought to gather data on the level of equipment infrastructure adaptability to Industry 4.0 functional requirements that enable a link between the physical and virtual worlds.

Section 4: Questions on operations assessed the concept of vertical and horizontal integration, which is the enterprise-wide and cross-enterprise integration of the physical and virtual worlds.

Section 5: Products questions measured the capability to gather data on products, know the way through production, and communicate with higher-level systems. Respondents were asked to identify product information and communication add-on functionalities offered by their organisations.

Section 6: Data-driven questions sought to measure how organisations evaluated and analysed data collected on enterprise-wide integration. Respondents were asked whether they gathered data on production and in the usage phase, and analysed data for continual improvement.

Section 7: Questions on employees assessed the availability of employee skills for digital transformation. Respondents were asked to evaluate the skills available in their organisation for future requirements under Industry 4.0.

\subsection{Sampling technique}

Sampling techniques are grouped as probability and non-probability sampling methods, among others [22-24]. The convenience sampling technique, which is a non-probability sampling method, is applicable to quantitative research [22] and was selected for this study. Etikan, Musa, and Alkassim [22] state that the type of non-probability sampling selected for a study depends on the type, nature, and purpose of the study.

This study is an exploratory one to obtain primary data from a general group of respondents, thus making convenience sampling appropriate for the study [25]. In addition, Kindle, in answering Gurung [26], stated that convenience sampling is totally acceptable in an area of study that is fundamentally new - in this case, Industry 4.0. The survey instrument is designed in such a way that an organisational readiness assessment can be provided by any individual at management level. Using the argument of Etikan et al. [22], convenience sampling suits this study in view of the possibly large size of the population and the need to reach as many participants as possible.

In carrying out a pilot study to assess the state of Industry 4.0 across German companies, Bittighofer et al. [10] used convenience sampling of the 30 available employees. In the current study, the researchers used the available network, which included the SAlIE $29^{\text {th }}$ conference contact list, Industry 4.0 platforms in South Africa [27], and Linkedln contacts, to reach out to potential respondents. The participants were randomly selected on condition that they held a management position. 
Etikan et al. [22] state that convenience sampling targets a population that satisfies practical criteria, such as ease of access, and that is keen to participate in the study. According to the researchers, easy accessibility can be interpreted to be the mode of identifying and accessing the population. In this study, online platforms were used to access potential participants, further justifying convenience sampling as an appropriate method.

The main disadvantage of convenience sampling is that it may be biased; the results would then not be representative of the population [22]. Skowronek and Duerr [28] pointed out that bias in convenience sampling can be eliminated by making the sample significantly representative, increasing its diversity by the way in which the survey instrument is distributed, and incorporating as much data as possible. In this study, convenience sampling bias was avoided by randomly distributing the questionnaire to as many people as possible in different industries, using different platforms.

\subsection{Data analysis}

Question 5 [29] of the questionnaire survey was an open-ended question, and could only be analysed qualitatively. Castleberry and Nolen [30] state that responses to open-ended questionnaire questions can be treated as qualitative data. The first three steps in the thematic analysis procedure outlined by Castleberry and Nolen [30] was used to analyse question 5 . Using the 25 first cycle coding methods presented by Saldana [31], descriptive codes were applied in performing this analysis. The amount of textual data collected in this question was notably small, justifying the use of manual analysis. The response to this question contributed zero points in the calculation of the readiness dimension score.

Using descriptive statistics is deemed a necessary data analysis approach when dealing with convenience sampling data [32]; so it was applied in this study. Although statistical analysis results from convenience sampling data are not necessarily generalisable beyond the sample [22, 24], inferential statistics tools were applied in determining whether there was a significant difference between the dimensions' contributions to the overall readiness level.

A discussion by a group of researchers of the answer to the question, "What are the statistical tests applicable to a study that has recruited participants using convenience sampling?", it was pointed out that any statistical tests can be used [33]. The only limitation is that the results cannot be generalised to a broader population.

Questions 6 to 24 were quantitative in nature, and were coded in order to calculate the total score for each readiness assessment dimension. Table 8 presents the possible total score for each readiness dimension, which was determined by finding the possible total score for each question and adding up these scores for the questions belonging to that specific readiness dimension. The total score for each question was determined in two ways: (a) assigning a value of 1 to all the positive responses, as required by the question, and adding up all the possible total scores; and (b) assuming the Likert scales to be interval data, converting the verbal Likert rating scale to a numeric Likert rating scale, and adding up all the possible total scores for the question. The possible total score was used to calculate the percentage score for each readiness assessment dimension.

Table 8: Possible total score for each readiness dimension

\begin{tabular}{l|l}
\hline Readiness dimension & Possible total score \\
\hline Organisational strategy & 36 \\
\hline Infrastructure & 39 \\
\hline Operations & 45 \\
\hline Products & 9 \\
\hline Data-driven services & 4 \\
\hline Employees & 27 \\
\hline
\end{tabular}

Table 9 shows the criteria that were used to identify the readiness level for each dimension. The overall readiness for each organisation was calculated using the proven VDMA [19] weighting percentages yardstick presented in Table 5, although these were originally established for the German industry, which has different constructs from the South African industry. It is assumed that, 
to assess Industry 4.0 readiness for any country in the true sense, the six dimensions should have similar weighting percentages in the assessment. The VDMA [19] and Siemens [5] models are merged to formulate the final categories in analysing the data.

Using the case of the VDMA [19], the dimension 'organisational strategy' had an additional criterion, which states that a company would automatically achieve level 0 if either question 6 or question 7 [29] carried zero points. This would make the dimension 'organisational strategy' carry no weight in the company's overall readiness level. Further to this, if respondents indicate that Industry 4.0 is not compatible with their organisation, this results in an overall readiness level of zero. Indicators in any questions contributed no score if the respondents chose not to enter any feedback.

Table 9: Readiness levels criteria by percentage $(X)[5,19]$

\begin{tabular}{l|l|l|l}
\hline Category & Readiness level & Description & Criteria \\
\hline \multirow{2}{*}{ Emerging } & Level 0 & Outsider & 0 \\
\cline { 2 - 4 } & Level 1 & Beginner & $0<\mathrm{X} \leq 30$ \\
\hline Developing & Level 2 & Intermediate & $30<\mathrm{X} \leq 65$ \\
\hline \multirow{2}{*}{ Established } & Level 3 & Experienced & $65<\mathrm{X} \leq 80$ \\
\cline { 2 - 4 } & Level 4 & Expert & $80<\mathrm{X} \leq 90$ \\
\hline Advanced & Level 5 & Top performer & $90<\mathrm{X} \leq 100$ \\
\hline
\end{tabular}

Organisations were categorised into three main clusters: small, medium, and large enterprises. Aigbavboa and Thwala [34], Mahembe [35], van Scheers [36], and Mago and Toro [37] agree that there is no one-size-fits-all formula for classifying organisations into small and medium enterprises $(\mathrm{SME})$.

This study uses the statistical definition of SME [35] that uses the number of employees as the quantifying factor. Table 10 presents a classification of organisations in terms of number of employees.

Table 10: Organisations' classification [34, 35, 38]

\begin{tabular}{l|l}
\hline Category & Number of employees $(\mathrm{Y})$ \\
\hline Small enterprises & $20 \leq \mathrm{Y}<50$ \\
\hline Medium enterprises & $50 \leq \mathrm{Y}<200$ \\
\hline Large enterprises & $\geq 200$ \\
\hline
\end{tabular}

Organisations were also further divided into five industry categories: manufacturing, mining, chemical, aerospace, and other. This was applied in the additional analysis of data obtained.

\section{SURVEY RESULTS AND ANALYSIS}

In this study, descriptive statistics and inferential statistics are used to analyse the primary data collected from the respondents. Section 4.1 will analyse the respondents' profile, and section 4.2 will outline the respondents' understanding of Industry 4.0. An assessment of the organisations' overall Industry 4.0 readiness is presented in section 4.3 . Section 4.4 presents the results analysis by readiness dimensions.

\subsection{Respondents' profile analysis}

The total number of respondents in this study was 36. The sample size used in this study is comparable to that in a similar study undertaken by Bittighofer et al. [10]. According to the province in which respondents' organisations are situated, 69 per cent were from Gauteng, representing the majority of the respondents; 14 per cent were from the Western Cape; Mpumalanga, Limpopo, KwaZulu-Natal, the Free State, and North-West all yielded the same representation of three per cent.

Figure 1 shows the respondents' organisation by industry category, with 42 per cent and 36 per cent of the representation from the categories 'Other' and 'Manufacturing' respectively. 
Figure 2 presents the respondents' organisations according to their size, as defined in Table 10 . The majority of respondents, 61 per cent, indicated that they were from large enterprises, with 14 per cent and 25 per cent respectively representing small and medium enterprises.

\subsection{Industry 4.0 definition analysis}

Despite belonging to large organisations and holding relatively high positions, 11 per cent of the respondents indicated that they had no idea what Industry 4.0 was. The "what, who, when, where, why, how" concept suggested by Castleberry and Nolen [30] was used to identify codes that described how respondents understood Industry 4.0. Table 11 summarises the findings of the thematic analysis.

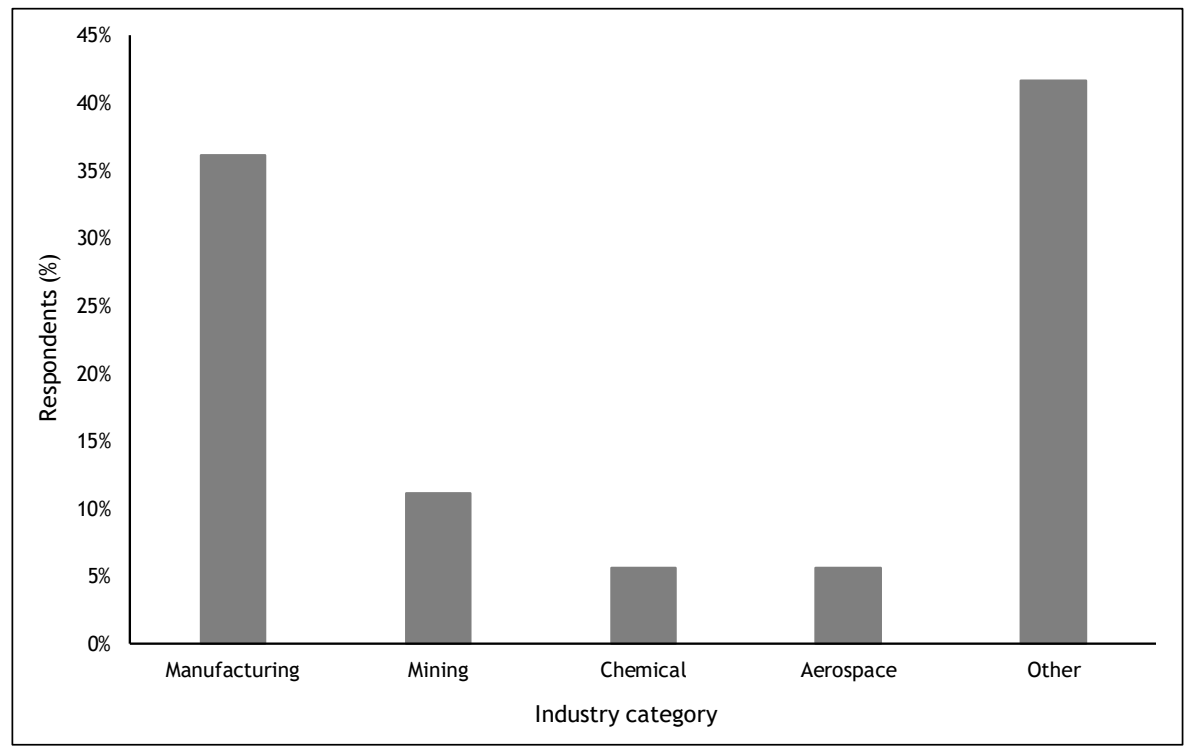

Figure 1: Respondents' companies by industry category

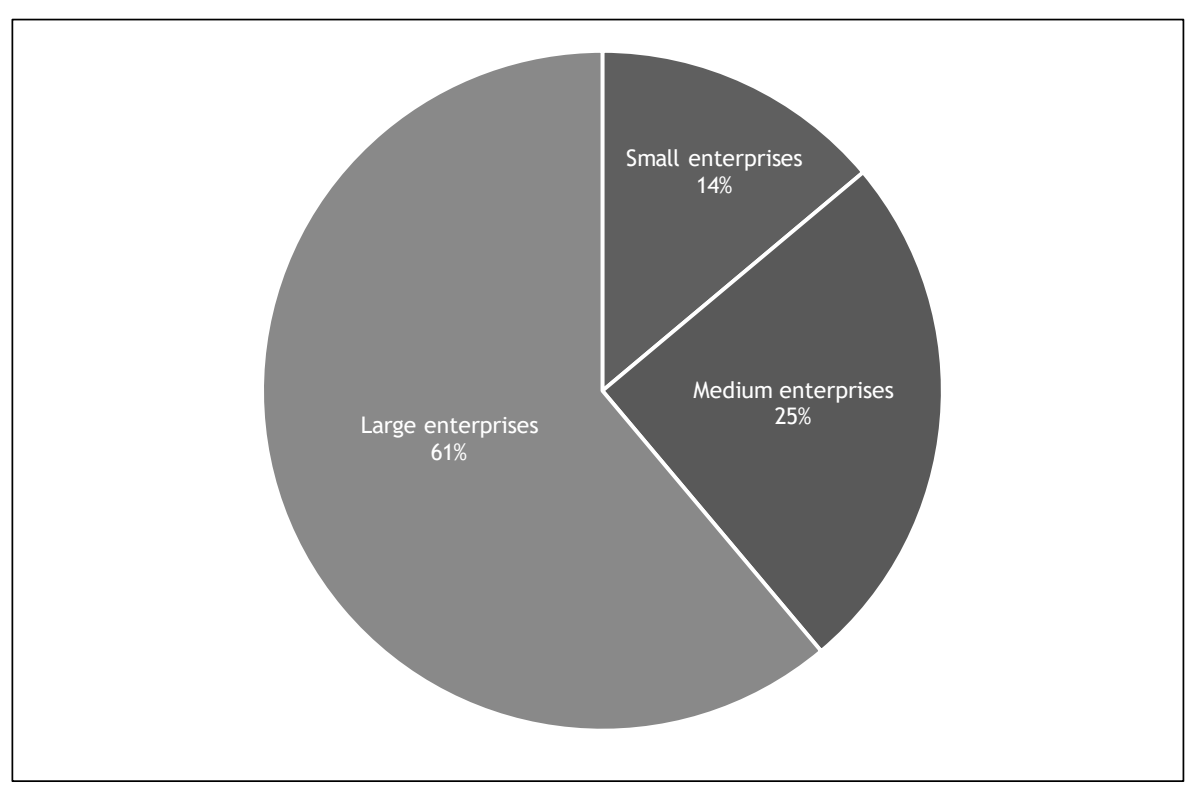

Figure 2: Representation by company size 
Table 11: Respondents' views on "What is Industry 4.0?"

\begin{tabular}{|c|c|c|}
\hline Theme & Codes & Comments \\
\hline What is involved? & $\begin{array}{l}\text { - } 4^{\text {th }} \text { industrial } \\
\text { revolution } \\
\text { - Technology } \\
\text { - Data } \\
\text { - Customisation }\end{array}$ & $\begin{array}{l}\text { Significant variation in understanding Industry } 4.0 \text {, with some } \\
\text { respondents pointing out that Industry } 4.0 \text { is synonymous with } \\
\text { the } 4^{\text {th }} \text { industrial revolution. Technological advancement and } \\
\text { data were viewed as enablers of Industry } 4.0 \text {. }\end{array}$ \\
\hline Who is involved? & $\begin{array}{l}\text { - People } \\
\text { - All business } \\
\text { - Industries } \\
\text { - Manufacturing }\end{array}$ & $\begin{array}{l}\text { Noticeable number of respondents were in agreement that } \\
\text { Industry } 4.0 \text { affects all industries and businesses and that it } \\
\text { involves people. However, there were others who defined it as } \\
\text { only applicable to the manufacturing industry. }\end{array}$ \\
\hline $\begin{array}{l}\text { When should it } \\
\text { take place? }\end{array}$ & $\begin{array}{l}\text { - Now } \\
\text { - Future }\end{array}$ & $\begin{array}{l}\text { Some saw Industry } 4.0 \text { as happening currently; others viewed it } \\
\text { as a future concept. }\end{array}$ \\
\hline $\begin{array}{l}\text { Why should it } \\
\text { happen? }\end{array}$ & $\begin{array}{l}\text { - Optimisation } \\
\text { - Competitiveness }\end{array}$ & $\begin{array}{l}\text { There was alignment in the thought that Industry } 4.0 \text { is meant to } \\
\text { achieve business optimisation and increase competitiveness. }\end{array}$ \\
\hline $\begin{array}{l}\text { How can it be } \\
\text { accomplished? }\end{array}$ & $\begin{array}{l}\text { - Integration } \\
\text { - Agility } \\
\text { - Connectivity } \\
\text { - Automation } \\
\text { - Digitalisation }\end{array}$ & $\begin{array}{l}\text { Respondents pointed out that Industry } 4.0 \text { will happen through } \\
\text { the integration of digital, biological, and physical technological } \\
\text { systems. A significant number of respondents pointed out that } \\
\text { connectivity and automation will drive Industry } 4.0 \text {. }\end{array}$ \\
\hline
\end{tabular}

Although respondents had different understandings of what Industry 4.0 is, there was agreement on what they thought was involved and why it should happen. The common understanding was that a large amount of data would be involved, and had to be analysed for the purpose of improving processes, systems, and services. Technological advancement was identified as one of the pillars of Industry 4.0 .

\subsection{Industry 4.0 overall readiness level}

\subsubsection{Overall readiness level}

Figure 3 presents the results of the organisations' overall Industry 4.0 readiness level. The analysis revealed that the overall Industry 4.0 readiness level for all the organisations that were considered in this study ranged between level 0 and level 3; 47 per cent of the organisations qualified for readiness level 2 , and 8 per cent were eligible for level 3.

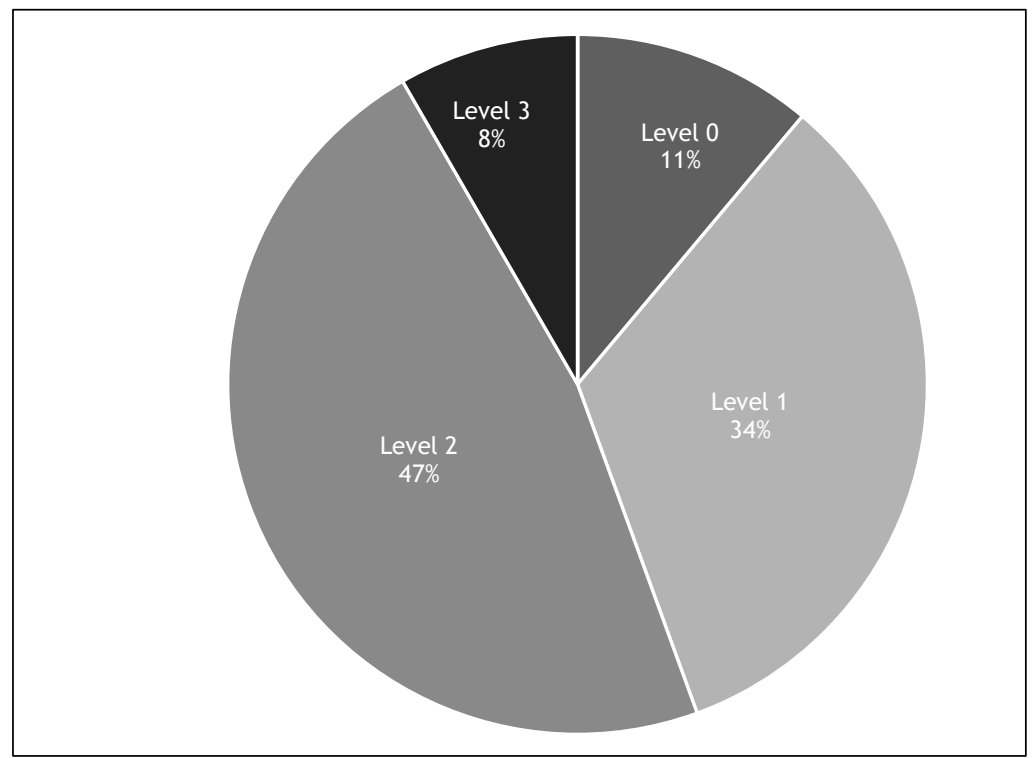

Figure 3: Organisations' overall Industry 4.0 readiness level

\subsubsection{Overall readiness level by size of the organisation means graph}

Figure 4 shows that the error bars in the means graph for the overall readiness level overlap. Accordingly, there is no significant difference between the mean average readiness level for small 
enterprises, medium enterprises, and large enterprises that are represented in this study within a 95 per cent confidence level ( $\mathrm{Cl}$ : 95 per cent). The graph shows that large enterprises have a smaller variance, meaning that they are more certain about their readiness level.

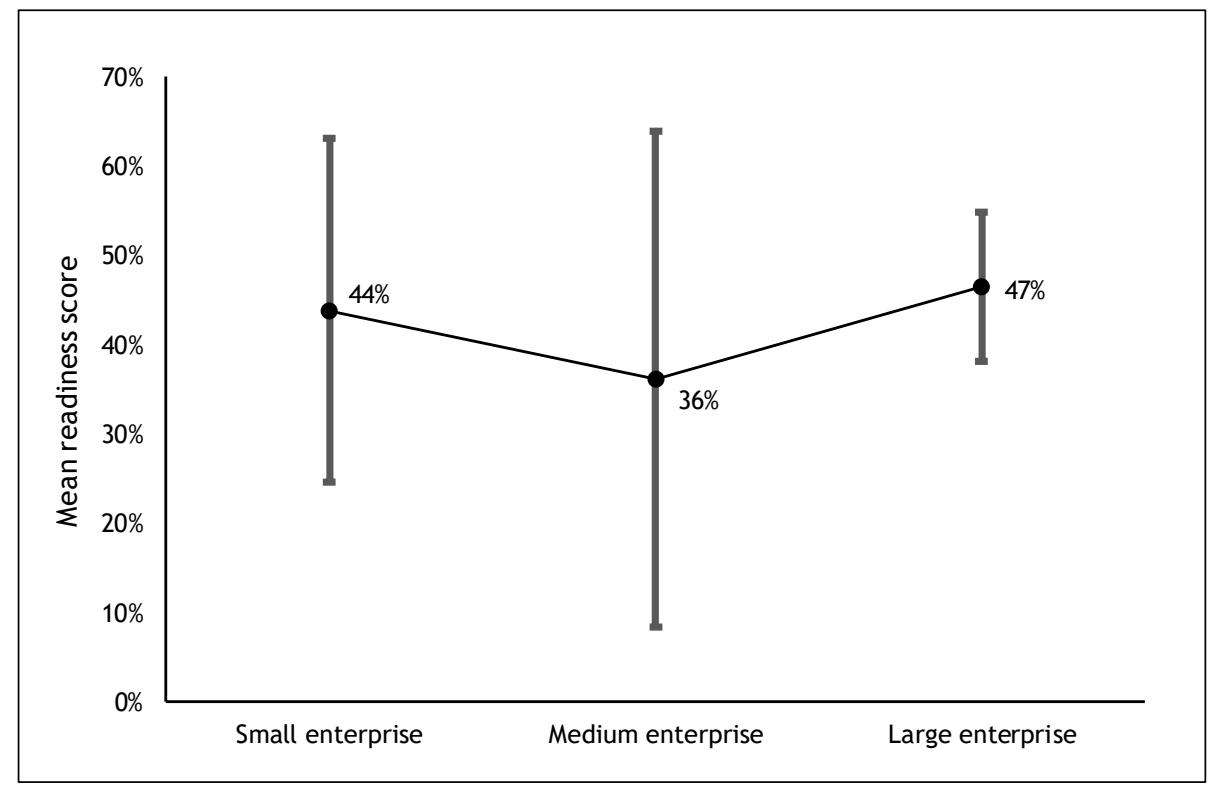

Figure 4: Overall readiness level score means graph $(\mathrm{Cl}: 95 \%)$

\subsubsection{ANOVA results}

To verify the means graph in Figure 4, an ANOVA test was performed. The results are presented in Table 12, and show that there is no need to perform t-tests.

Table 12: ANOVA analysis results

\begin{tabular}{l|l|l}
\hline Test & P-value & Conclusion \\
\hline ANOVA results & 0.394 & $\begin{array}{l}\text { There is no statistical difference between the organisational sizes' } \\
\text { average readiness percentage scores. }\end{array}$ \\
\hline
\end{tabular}

\subsection{Industry 4.0 readiness by dimension}

\subsubsection{Readiness dimension means graph}

The readiness dimension means graph is presented in Figure 5 . The error bars in the means graph overlap, indicating that there is no significant difference between the contribution of any readiness dimensions to the overall readiness level ( $\mathrm{Cl} 95$ per cent).

\subsubsection{ANOVA and $t$-test analysis results}

To verify the means graph findings in Figure 5 , a null hypothesis $\left(\mathrm{H}_{0}\right)$ and alternative hypothesis $\left(\mathrm{H}_{\mathrm{A}}\right)$ were formulated and tested using ANOVA and the respective t-test.

$H_{0}$ : There is no significant statistical difference in contribution to the Industry 4.0 overall readiness level between the six readiness dimensions.

$H_{A}$ : There is a significant statistical difference in contribution to the Industry 4.0 overall readiness level between the six readiness dimensions.

Table 13 presents the ANOVA results performed on the dimensions' contribution to the overall readiness level. The ANOVA test results show that there is a need to perform a t-test between each pair of the dimensions. 


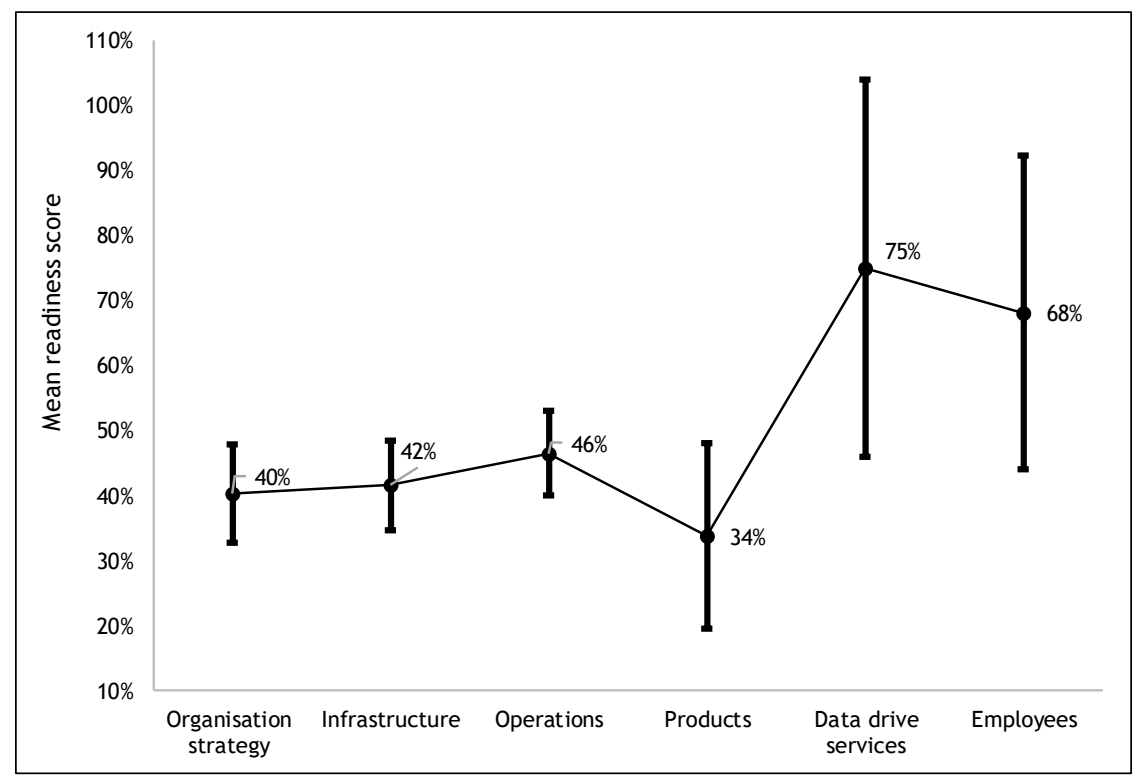

Figure 5: Readiness dimension means graph ( $\mathrm{Cl}$ : 95\%)

Table 13: ANOVA analysis results

\begin{tabular}{l|l|l}
\hline Test & P-value & Conclusion \\
\hline ANOVA results & $6.2 \times 10^{-14}$ & $\begin{array}{l}\text { There is a statistical difference between at least two dimensions in } \\
\text { contributing to overall readiness }\end{array}$ \\
\hline
\end{tabular}

Table 14 presents the t-test results. The number in each cell represents the $p$-value. The results show that there is no significant statistical difference in contributing to the overall readiness level between organisational strategy, infrastructure, operations, and products. On the other hand, no noticeable statistical difference exists between data-driven services and employees in contributing to the overall readiness level.

Table 14: $t$-test analysis results ( $p$-value)

\begin{tabular}{l|c|c|c|c|c}
\hline & Infrastructure & Operations & Products & Employees & Data-driven services \\
\hline Strategy & 0.08 & 0.11 & 0.24 & $5,3 \times 10^{-6}$ & $4.9 \times 10^{-7}$ \\
\hline Infrastructure & & 0,29 & 0,14 & $6,3 \times 10^{-6}$ & $6,4 \times 10^{-7}$ \\
\hline Operations & & & 0.05 & $1.3 \times 10^{-4}$ & $1.0 \times 10^{-5}$ \\
\hline Products & & & & $1.9 \times 10^{-7}$ & $2.4 \times 10^{-8}$ \\
\hline Employees & & & & & 0.29 \\
\hline
\end{tabular}

No significant difference between the two dimensions

Significant difference between the two dimensions

\section{DISCUSSION OF RESULTS}

Results from the respondents reveal that, although respondents have different understandings of what Industry 4.0 is, there is agreement on what is involved and why Industry 4.0 should happen. The common understanding is that Industry 4.0 involves huge amounts of data that must be analysed for the purpose of improving processes, systems, and services. A significant number of respondents pointed out that technological advancement is one of the pillars and enablers of Industry 4.0. However, some respondents still have a narrow understanding of Industry 4.0 - an indication that promoting awareness of Industry 4.0 to create common understanding is necessary. 
The Industry 4.0 overall readiness level results indicated that 45 per cent of the organisations are at the emerging level. Emerging level organisations comprise 11 per cent of those who have done nothing and have no intention of doing anything. Another 34 per cent are at the beginning stage. The results further indicated that 47 per cent of organisations are at the developing stage, while eight per cent claim to have elements of being established. On average, it is evident that small, medium, and large enterprises are all more-or-less in the same range of readiness for Industry 4.0.

In total, 80 per cent of the respondents pointed out that their organisations were in the emerging category (47 per cent) or developing category (33 per cent) in terms of Industry 4.0 organisational strategy. The organisations in the emerging category either have no existing Industry 4.0 strategy, or they have launched pilot initiatives. This could be interpreted as a lack of commitment to drive Industry 4.0 initiatives in a significant number of organisations in South Africa.

The results indicated that a number of organisations experience significant challenges in areas of equipment infrastructure that support Industry 4.0 requirements. In total, 84 per cent of organisations are in the emerging category ( 42 per cent) or developing category ( 42 per cent). These results could be interpreted as a significant number of organisations in South Africa not having equipment infrastructure that supports Industry 4.0 requirements. Further to this, their equipment functionalities might not be upgradable to Industry 4.0 requirements.

Regarding smart operations, 78 per cent of organisations are in the emerging category (28 per cent) or developing category (50 per cent). This could be an indication that a significant number of organisations are not prepared for vertical and horizontal integration of the physical world and virtual worlds. In addition, Industry 4.0 technical requirements for production and production planning might not be fulfilled. Regarding products' readiness for Industry 4.0, 97 per cent of organisations belong to the emerging category ( 72 per cent) or developing category ( 25 per cent). The result could be interpreted as organisations' current products not having functionalities that that meet Industry 4.0 requirements.

Contrary to the other four Industry 4.0 readiness dimensions, 51 per cent of the respondents pointed out that their organisations are in the established category (34 per cent) or advanced category (17 per cent) regarding employees' skills requirements. This could be interpreted as Industry 4.0 skills existing in South African, although these might be inadequate. In support of the current literature on the availability status of Industry 4.0 skills, the results could be interpreted as respondents failing to recognise the skills required for Industry 4.0. This is an indication that further study in this area is essential.

In total, 56 per cent of the respondents indicated that their organisations were in the established category ( 25 per cent) or advanced category ( 31 per cent). This could be interpreted as a significant number of organisations collecting digital data and analysing it for continuous improvement purposes.

The ANOVA and t-test results proved the point that employee skills requirements and data-driven services differ significantly from the other four dimensions in their contribution to overall readiness for Industry 4.0. Although this could not be generalised beyond the sample used, the statistical results proved the points discussed in this section.

\section{6}

CONCLUSION

Knowing one's Industry 4.0 readiness status is fundamental to the successful adoption and embracing of digital transformation. This exploratory study uncovered significant shortfalls in the area of Industry 4.0 strategy in organisations. A noticeable number of organisations do not have an existing strategy, which is the driver of the adoption of Industry 4.0. Although this might not be a full representation of all South African industries, the study revealed that there are noticeable challenges in terms of equipment infrastructure that supports Industry 4.0 and equipment functionalities' upgradability to meet Industry 4.0 requirements. The exploratory study pointed out that Industry 4.0 skills in South Africa exist in pockets. South African industry could be categorised as partially emerging and partially developing in the area of digital transformation, according to this exploratory study. Further study to reveal more detail on Industry 4.0 skills requirements is essential. 


\section{REFERENCES}

[1] Hermann, M., Pentek, T. and Otto, B. 2016. Design principles for industrie 4.0 scenarios. In 201649 th Hawaii international conference on system sciences (HICSS). Koloa, HI, USA: IEEE.

[2] Bartodziej, C.J. 2017. The concept industry 4.0, in The concept industry 4.0. Bartodziej, Berlin: Springer, pp. 27-50.

[3] Chung, M. and Kim, J. 2016. The internet information and technology research directions based on the Fourth Industrial Revolution. KSII Transactions on Internet \& Information Systems, 10(3), pp.1311-1320.

[4] Min, Y.K., Lee, S.G. and Aoshima, Y. 2019. A comparative study on industrial spillover effects among Korea, China, the USA, Germany and Japan. Industrial Management \& Data Systems, 119(3), pp. 454-472.

[5] Siemens. 2017. African Digitalization Maturity Report. Siemens, pp. 1-45.

[6] Albers, A., Gladysz, B., Pinner, T., Butenko, V. and Sturmlinger, T. 2016. Procedure for defining the system of objectives in the initial phase of an industry 4.0 project focusing on intelligent quality control systems. Procedia Cirp, 52, pp. 262-267.

[7] Lu, Y. 2017. Industry 4.0: A survey on technologies, applications and open research issues. Journal of Industrial Information Integration, 6, pp. 1-10.

[8] Schwab, K. 2016. The Fourth Industrial Revolution: What it means, how to respond. [Cited 14 December 2018]; available from: https://www.weforum.org/agenda/2016/01/the-fourth-industrial-revolutionwhat-it-means-and-how-to-respond/.

[9] Rajnai, Z. and Kocsis, I. 2018. Assessing industry 4.0 readiness of enterprises. In 2018 IEEE 16th World Symposium on Applied Machine Intelligence and Informatics (SAMI). Košice, Herl'any, Slovakia: IEEE, pp.000225-000230

[10] Bittighofer, D., Dust, M., Irslinger, A., Liebich, M. and Martin, L. 2018. State of Industry 4.0 across German companies. In 2018 IEEE International Conference on Engineering, Technology and Innovation (ICE/ITMC). Stuttgart, Germany: IEEE.

[11] Basl, J. 2017 Pilot study of readiness of Czech companies to implement the principles of Industry 4.0. Management and Production Engineering Review, 8(2), pp. 3-8.

[12] InTechCentras. 2018. Industry 4.0 Audits [Cited 12 December 2018]; available from: http: / /intechcentras.lt/wp-content/uploads/2017/08/i40-Audits.pdf.

[13] Botha, A.P. 2018. Rapidly arriving futures: future readiness for Industry 4.0. South African Journal of Industrial Engineering, 29(3): pp. 148-160.

[14] Judit, N. 2018. Industry 4.0: How to assess the readiness of firms. Economics and Business Studies, pp. 151-160.

[15] Blanchet, M., Rinn, T., Thaden, T.V. and De Thieulloy, G. 2014. Industry 4.0 The new industrial revolution How Europe will succeed. Roland Berger Strategy Consultants, Munich, pp. 1-24.

[16] Geissbauer, R., J. Vedso, and S. Schrauf. 2016. Industry 4.0: Building the digital enterprise. [Cited 12 December 2018]; available from: https://www.pwc.com/gx/en/industries/industries-4.0/landingpage/industry-4.0-building-your-digital-enterprise-april-2016.pdf.

[17] Basl, J. and J. Kopp. 2017. Study of the Readiness of Czech Companies to the Industry 4.0. Journal of Systems Integration, 8(3), pp. 40-45.

[18] IMPULS. 2015. Industry 4.0 Readiness: Online self-check for businesses. [Cited 14 December 2018]; available from: https: //www.industrie40-readiness.de/.

[19] Lightblau, K., Sting, V., Bertenrath, R., Blum, M., Bleider, M., Millack, A., Schmitt, K., Schmitz, E. and Schroter, M. 2015. Industrie 4.0 readiness. Cologne Institute for Economic Research (IW), Frankfurt, pp. 78.

[20] Samaranayake, P., Ramanathan, K. and Laosirihongthong, T. 2017. Implementing Industry 4.0-A technological readiness perspective. In 2017 IEEE International Conference on Industrial Engineering and Engineering Management (IEEM). Singapore: IEEE, pp. 529-533.

[21] Hamidi, S.R., Aziz, A.A., Shuhidan, S.M., Aziz, A.A. and Mokhsin, M. 2018. SMEs maturity model assessment of IR4. 0 digital transformation. In 2018 International Conference on Kansei Engineering \& Emotion Research (KEER). Singapore: Springer, pp. 721-732.

[22] Etikan, I., Musa, S.A. and Alkassim, R.S. 2016. Comparison of convenience sampling and purposive sampling. American Journal of Theoretical and Applied Statistics, 5(1): pp. 1-4.

[23] Sedgwick, P. Convenience sampling. 2013. [Cited 12 February 2019]; available from: https://www.researchgate.net/profile/Philip_Sedgwick/publication/291161903_Convenience_sampling/l inks/569e722408ae4af5254463e1/Convenience-sampling.pdf.

[24] Acharya, A.S., Prakash, A. and Nigam, A. 2013. Sampling: Why and how of it?. Indian Journal of Medical Specialties, 4(2), p. 330-333.

[25] Vrechopoulos, A.P., Constantiou, I.D., Mylonopoulos, N. and Sideris, I. 2002. Critical success factors for accelerating mobile commerce diffusion in Europe. In 2002 15th Bled Electronic Commerce Conference eReality: Constructing the eEconomy. Bled, Slovenia, pp. 477-492.

[26] Gurung, D.J. 2019. Which statistical method can be done on convenience sample? [Cited 08 March 2019]; available from: https://www.researchgate.net/post/Which_Statistical_analysis_can_be_done_on_convenience_sample.

[27] 4IR-SA. 2019. Industrial Engineering PhD student at North-West University requesting your assistance. [Cited 08 March 2019]; available from: http://4ir.co.za/articles/industrial-engineering-phd-student-atnorthwest-university-requesting-your-assistance/. 
[28] Skowronek, D. and Duerr, L. 2009. The convenience of nonprobability: Survey strategies for small academic libraries. College and Research Libraries News, 70(7), pp. 412-415.

[29] Maisiri, W. 2019. Industry 4.0 assessment. [Cited 08 April 2019]; available from: https://docs.google.com/forms/d/e/1FAlpQLSdbBLnv-e88zpwtjZB4ZIPVsF_6fdxa2j_KZ2GuX0co970bg/viewform?usp=sf_link.

[30] Castleberry, A. and Nolen, A. 2018. Thematic analysis of qualitative research data: Is it as easy as it sounds?. Currents in Pharmacy Teaching and Learning,10(6), pp. 807-815.

[31] Saldaña, J. 2013. The coding manual for qualitative researchers. $2^{\text {nd }}$ Edition, Sage Publications, London, pp. 87-90.

[32] Price, M. 2013. Convenience samples: what they are, and what they should (and should not) be used for. [Cited 13 December 2019]; available from: https://hrdag.org/2013/04/05/convenience-samples-whatthey-are/.

[33] Pundhir, A. 2016. What are the statistical tests applicable for study that has recruited participants using convenience sampling? [Cited 08 March 2019]; available from: https://www.researchgate.net/post/What_are_the_statistical_tests_applicable_for_study_that_has_recr uited_participants_using_convenience_sampling.

[34] Aigbavboa, C.O. and Thwala, W.D. 2014. Challenges facing black owned small and medium construction companies: A case study of Nelspruit-Mbombela Municipality, South Africa. Journal of Economics and Behavioral Studies, 6(10): pp. 771-778.

[35] Mahembe, E. 2011. Literature review on small and medium enterprises' access to credit and support in South Africa. Underhill Corporate Solutions. National Credit Regulator (NCR), Pretoria, pp.22-30.

[36] van Scheers, L. 2018. Strategies of global recession for small business enterprises in emerging markets: Case of South Africa. Journal of Business and Retail Management Research, 12(2), pp. 163-172.

[37] Mago, S. and Toro, B. 2013. South African government's support to small, medium micro-enterprise (SMMEs): the case of King William's Town area. Journal of Economics, 4(1): pp. 19-28.

[38] Ayandibu, A.O. and Houghton, J. 2017. The role of Small and Medium Scale Enterprise in local economic development (LED). Journal of Business and Retail Management Research, 11(2), pp. 133-139. 